\title{
The effect of calving season and age at calving on production traits of South African dairy cattle
}

\author{
B.E. Mostert ${ }^{\#}$, H.E. Theron and F.H.J. Kanfer ${ }^{1}$ \\ ARC-Animal Improvement Institute, Private Bag X2, Irene 0062, South Africa \\ ${ }^{1}$ Department of Statistics, University of Pretoria, Pretoria 0002, South Africa
}

\begin{abstract}
Lactation records of South African Holstein and Jersey cows were classified into six calving seasons and 18 age $\mathrm{x}$ lactation classes using several trials involving analysis of variance and estimation of fixed effects of calving age on test-day as well as 305-day yields. Best Linear Unbiased Estimates for the effect of season and age $\mathrm{x}$ lactation were derived using an animal model following the prediction of daily milk, butterfat and protein yields on fixed days-in-milk and of cumulative 305-day yields by linear interpolation. For both breeds, test-day and cumulative 305-day yields were higher for cows calving in mid-winter (June/July) compared to cows calving in mid-summer (December/January). Daily yields early in the lactation were more influenced by calving age than daily yields towards the end of the lactation. Cows that calved at younger ages in lactations 1 and 2 produced less milk compared to cows calving at older ages over the entire lactation. Second and later parity cows had higher test-day yields than heifers for most stages of the lactation. These estimates can be used to adjust test-day and cumulative yields for the effect of season and age class, thereby enabling the determination of herd levels and the derivation of standard lactation curves and projection factors for South African Holstein and Jersey cows.
\end{abstract}

Keywords: age at calving, Best Linear Unbiased Estimates, Holstein, Jersey, season of calving.

\#Author to whom correspondence should be addressed. E-mail: bernice@idpi1.agric.za

\section{Introduction}

In South Africa 80316 Holstein and 37505 Jersey cows participated in performance testing during the 1999/2000 test year. This represents $64 \%$ and 30\% respectively of the total number of dairy breed cows participating in performance testing (Du Toit \& Hallowell, 2001). Breeding values for 305-day milk, butterfat and protein yield, as well as butterfat and protein percentages in first lactations are predicted for purposes of genetic improvement programs. A cow's test-day yield is influenced by systematic environmental effects such as age and season of calving, stage of lactation, herd and number of days open (Danell, 1982). Correct adjustment for age and season of calving are the basis for predicting breeding values and calculating management guides (Wilmink, 1987a). Classification of lactation records by calving season, age at calving and herd level of production are also necessary to facilitate the adjustment of records for these factors in the derivation of standard lactation curves as well as projection factors (Olori \& Galesloot, 1999). The aim of this study was therefore to classify lactation records of South African Holstein and Jersey cows by calving season and age at calving and to derive adjustment factors for these effects in order to predict lactation parameters. Possible differences between Holstein and Jersey cows were also studied.

\section{Materials and Methods}

Test-day lactation records for milk, butterfat and protein yield of Holstein cows with lactations completed over a three year period and Jersey cows with lactations completed over a 10 year period were obtained from the INTERGIS for cows participating in the South African Dairy Animal Improvement Scheme. Test-day records for Holstein cows were limited to a three year period due to the large number of records available for the breed. Lactations were selected from the available data for further analyses, according to the following criteria: (a) lactations should have at least four test-day records; (b) intervals between consecutive tests should not exceed 75 days, (c) parity number should be consistent with calving date; (d) maximum test-day milk yield should not exceed $90 \mathrm{~kg}$ for Holstein or $50 \mathrm{~kg}$ for Jersey cows and minimum test-day milk yield should not be less than $1 \mathrm{~kg}$; (e) duration of lactation should be at least 250 days and the interval from calving to first test-day should not exceed 50 days. Records with unknown butterfat and protein 
yields were deleted and age restrictions were set for calving in the different lactations. As a result, $21 \%$ of the Holstein and 8\% of the Jersey test-day records were deleted, leaving 2537577 test-day records of 116073 cows, 321304 lactations in 1590 herds for the Holsteins and 1673972 test-day records of 90825 cows, 210 320 lactations in 1182 herds for the Jerseys.

Six seasons of calving were defined. Each season comprised a two calender month period. The first class consisted of cows calving in December/January, while the last consisted of cows calving in October/November. Records were subsequently grouped into 18 classes depending on parity and age at calving. This was done following several trials involving analysis of variance and estimation of fixed effects of calving age on test-day as well as 305-day yields. Age was grouped within parity because of the high variation in age within parity. An analyses of variance was done to determine the effect of the allocated season and age classes on 305-day milk, butterfat and protein yield of the Holstein and Jersey data.

The test interval method (TIM) can be used to calculate cumulative yields from test-day yields by linear interpolation. This method is, however, limited by its dependence on the intervals between the test-days and failure to take the pattern of production around the peak yield into account. For example, if the first two tests are taken before and after peak yield for a non-persistent cow, the mean yield in that interval, obtained by linear interpolation, will be lower than the actual mean yield, resulting in a lower cumulative yield. With interpolation using the standard lactation curves, individual lactation curves are calculated for each cow. The individual lactation curves are based on derived daily yields on set fixed days-in-milk in addition to measured daily yields. The fixed days-in-milk are chosen at intervals of 20 days with the first on lactation day 10. This ensures that there are at least 15 test-day yields at intervals of at most 20 days for deriving each cow's lactation curve. The yield for each of the fixed test-days-in-milk is derived by interpolation from surrouding records for the fixed days before the last test. Yields on fixed days before the first test and after the last test are predicted. Standard lactation curves apply as a guide for the derivation of the daily yields on the fixed days. Therefore, to ensure that all cows had yields on the same test-days for subsequent analyses, daily milk, butterfat and protein yields were predicted for fixed days-in-milk for all cows not having an observed yield on that specific test-day. Yields were therefore predicted from day 10 to day 290 with 20 day intervals. Daily yields for those fixed days before the first test and after the last test were estimated by fitting a lactation curve function derived by Wilmink (1987b) to the available test-day records of each cow using SAS (1996). Lactations without test-day records after 230 days-in-milk were deleted. The following curve function was used:

Where

$y_{t} \quad=\quad$ milk, butterfat or protein yield predicted for fixed day $\mathrm{t}$

$\beta_{0,} \beta_{1}$ and $\beta_{2}=$ coefficients of the lactation curve function

$e_{t} \quad=$ residual error

Missing yields for fixed days-in-milk within the first and last observed test-day yields were obtained by interpolating between successive observed yields. This was to ensure that the derived lactation curve for each cow was as close to the observed curve as possible. Using estimates predicted from fitting the curve function would result in a smooth curve, which may be different from the observed pattern of yields, especially for cows calving in autumn which normally have a 'spring hump' in their lactation curves. After predicting the yields on the fixed days-in-milk, lactations with extreme values predicted for the first test on day 10 of lactation were deleted. A test yield was considered extreme if it was larger or lower than the mean plus two times the standard deviation of the yields predicted for day 10. Following these procedures 25428 lactations were deleted for the Holstein and 11303 lactations for the Jersey breed.

A 305-day yield was estimated for each of the remaining lactation records by linear interpolation from the 15 test-day yields available for each cow, using the function proposed by Olori \& Galesloot (1999):

Where

$$
Y_{305}=20\left(y_{10}+y_{30}+\ldots \ldots .+y_{290}\right)+5\left(y_{290}\right)
$$

$Y_{305}=305$-day milk, butterfat or protein yield

$y_{n}=$ test-day yield (observed or derived) for the fixed day in milk $\mathrm{n}$, for $\mathrm{n}=10,30,50,70$,

$90,110,130,150,170,190,210,230,250,270,290$ ) 
Separate Best Linear Unbiased Estimates (BLUEs) for herd, age class and season were calculated per fixed day in milk, using PEST (Groeneveld \& Kovac, 1990) and the following animal model :

Where

$$
y_{i j k l m n}=\mu+H_{j}+A_{k}+S_{l}+G_{m}+e_{n}
$$

$y_{i j k l m n}=\quad \mathrm{i}^{\text {th }}$ test-day milk, butterfat or protein yield of cow $\mathrm{m}$ in herd $\mathrm{j}$, age class $\mathrm{k}$, calving in season $\mathrm{l}$

$\mu \quad=\quad$ mean yield

$H_{j} \quad=\quad$ fixed effect of herd $\mathrm{j}(\mathrm{j}=1, \ldots, 1159$ for Jerseys $)$ and $(\mathrm{j}=1, \ldots ., 1580$ for Holsteins $)$

$A_{k}=$ fixed effect of age class $\mathrm{k}(\mathrm{k}=1, \ldots, 18)$

$S_{l} \quad=\quad$ fixed effect of calving season $1(1=1, \ldots, 6)$

$G_{m}=$ additive genetic effect of animal $\mathrm{m}$

$e_{n} \quad=\quad$ random residual error

Univariate analyses were therefore done separately for each of the 15 test-days, including data of all herds, all lactations and all seasons in every run and also using pedigree information to estimate the animal effect.

\section{Results and Discussion}

Cows of both breeds calved throughout the year (Figure 1) with slightly more calvings in the mid-winter season (20\% for the Jersey; $19 \%$ for the Holstein in June/July) than in the mid-summer season (14\% for the Jersey; $16 \%$ for the Holstein in December/January). Olori \& Galesloot (1999) observed a definite calving season for Holstein cows in Ireland. Cows calving between February and March contributed the highest number of records $(36 \%)$, while the lowest number $(2 \%)$ was from cows calving between June and July in the northern hemisphere. The large difference in number of lactations for the two breeds is a reflection of the difference in population size of the two breeds in South Africa. Of all registered dairy animals (including goats) participating in performance testing during 1999/2000, 55\% were Holstein cows and 39\% were Jersey cows.

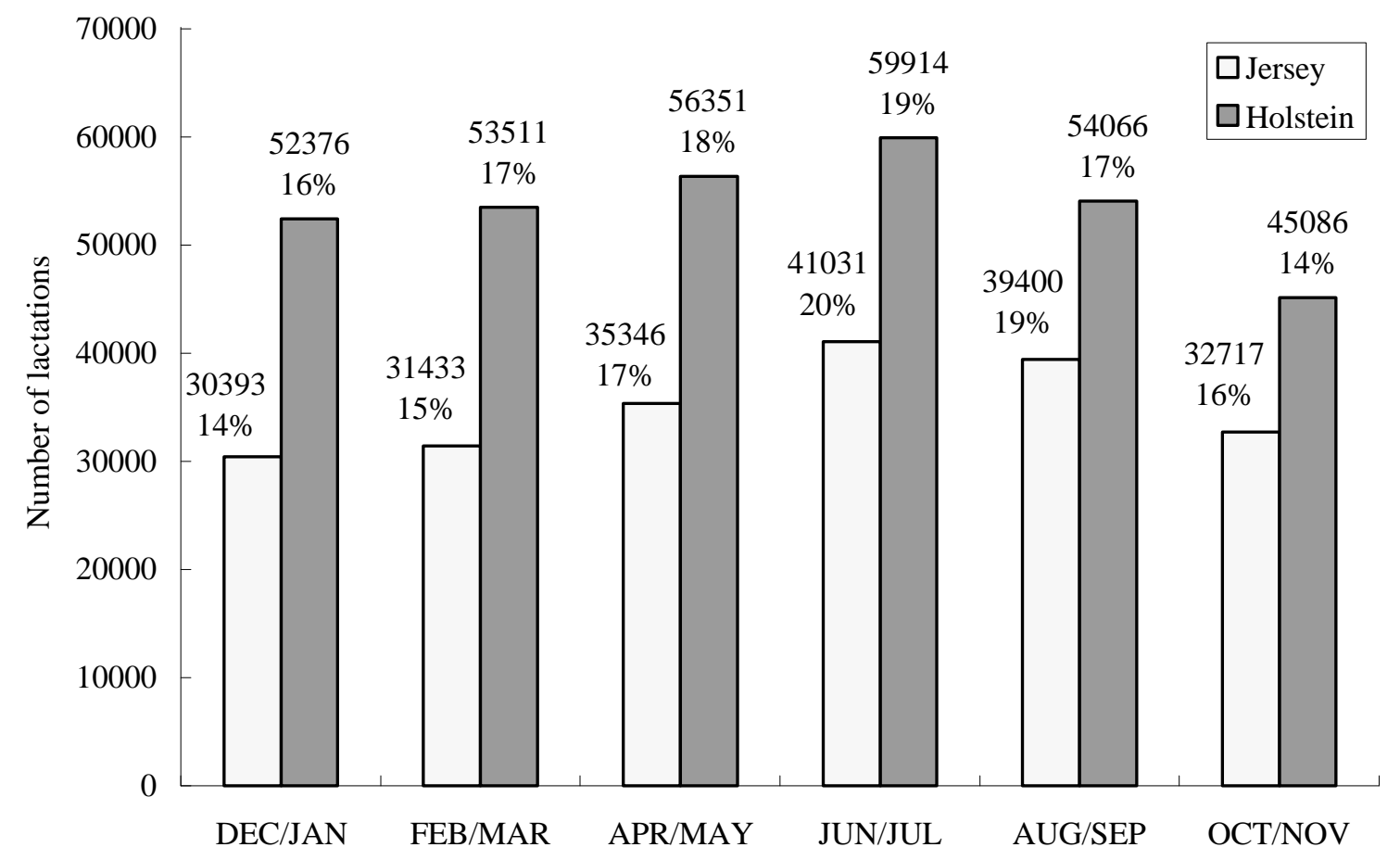

Figure 1 Distribution of lactation records by calving season for Jersey and Holstein cows.

Figure 2 shows the final classification of lactation records for age at calving and the percentage of records in each class for each breed. It was concluded that Jersey breeders tend to breed heifers earlier than Holstein breeders because $7 \%$ of Jersey cows were younger than 24 months of age when they calved for the first time compared to $1 \%$ of Holstein cows. 


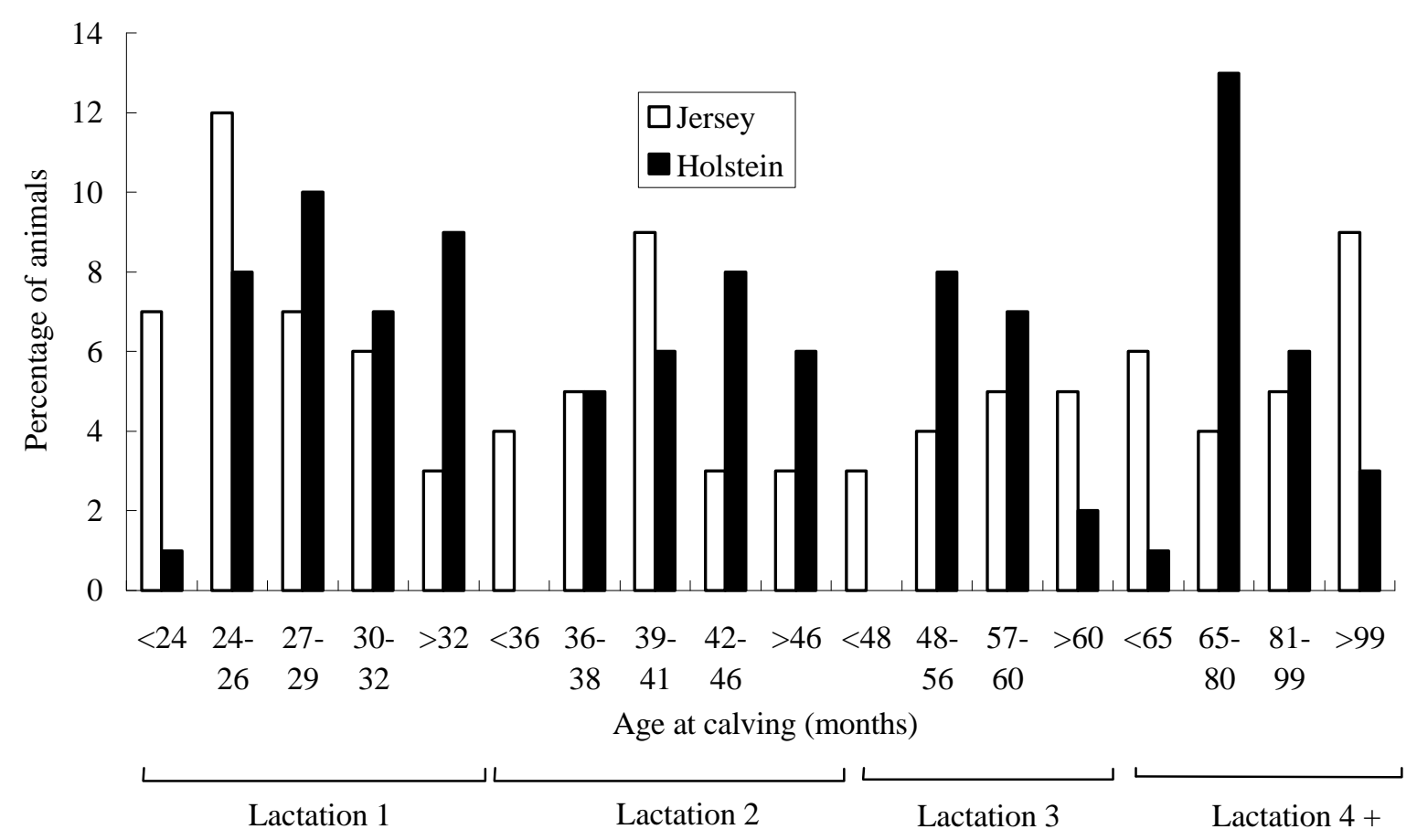

Figure 2 Distribution of lactation records by age at calving for Jersey and Holstein cows.

Results of the analyses of variance are given in Table 1. These results confirm that the categories of season and age class were effectively allocated.

Table 1 Analyses of variance for 305-day milk, butterfat and protein yields for Jersey and Holstein cows (P $\leq$ 0.0001 for all effects)

\begin{tabular}{cccccccc}
\hline & & & Jersey & & & Holstein & \\
Trait & Source & $\mathrm{df}$ & $\mathrm{F}$ & $\mathrm{R}^{2}$ & $\mathrm{df}$ & $\mathrm{F}$ & $\mathrm{R}^{2}$ \\
\hline Milk & Herd & 1181 & 151.6 & 0.52 & 1589 & 310.1 & 0.64 \\
& Season & 5 & 254.6 & & 5 & 475.5 & \\
& Age class & 17 & 3074.5 & & 17 & 4921.6 & \\
& Residual & 209116 & & & 319692 & & \\
& Total & 210319 & & & 321303 & & \\
& & & & & & & \\
Fat & Herd & 1181 & 160.6 & 0.52 & 1589 & 303.1 & 0.63 \\
& Season & 5 & 181.2 & & 5 & 390.6 & \\
& Age class & 17 & 2739.1 & & 17 & 4328.7 & \\
& Residual & 209116 & & & 319692 & & \\
& Total & 210319 & & & 321303 & & \\
& & & & & 1589 & 339.7 & 0.66 \\
Protein & Herd & 1181 & 172.2 & 0.55 & 17.7 & \\
& Season & 5 & 224.1 & & 5 & 347.7 & \\
& Age class & 17 & 224.1 & & 17 & 4828.2 & \\
& Residual & 209116 & 3454.6 & & 319692 & & \\
& Total & 210319 & & & 321303 & & \\
\hline
\end{tabular}

Herd, season and age class had an effect $(\mathrm{P}<0.0001)$ on 305-day milk, butterfat and protein yield, 
explaining on average $64 \%$ of the variation in the Holstein and 53\% in the Jersey breed. Of these effects, age class contributed most to the variation in all traits of both breeds. Age and season factors for test-day yields are dependent on stage of lactation (Wilmink, 1987a). Dommerholt (1975) found that age at calving accounted for about $46 \%$ of the variation in daily milk yield at the beginning of lactation, which decreased to about $5 \%$ at the end. Season of calving accounted for about $1 \%$ at the beginning and increased to about $8 \%$ at the end of lactation. Auran (1973), Dommerholt (1975) and Cooper \& Hargrove (1982) reported that age explains from 20-40\% of the total sums of squares. The Best Linear Unbiased Estimates of the effect of season for daily milk yields of Jersey cows and protein yields of Holstein cows are presented in Figures 3 and 4. Although the effects were larger for the Holstein breed, the effect of season on daily yields was similar for all traits and both breeds. Estimates of yield on day 10 were based mostly on extrapolated data, as few lactations had test-day yields recorded before day 30 post partum. Season had a distinct effect on the shape of the lactation curve. Cows calving in June/July had a typical lactation curve, which differed from the curve of cows calving in December/January. The highest daily yields were obtained from cows calving in the cooler months (April/May, June/July and August/September).

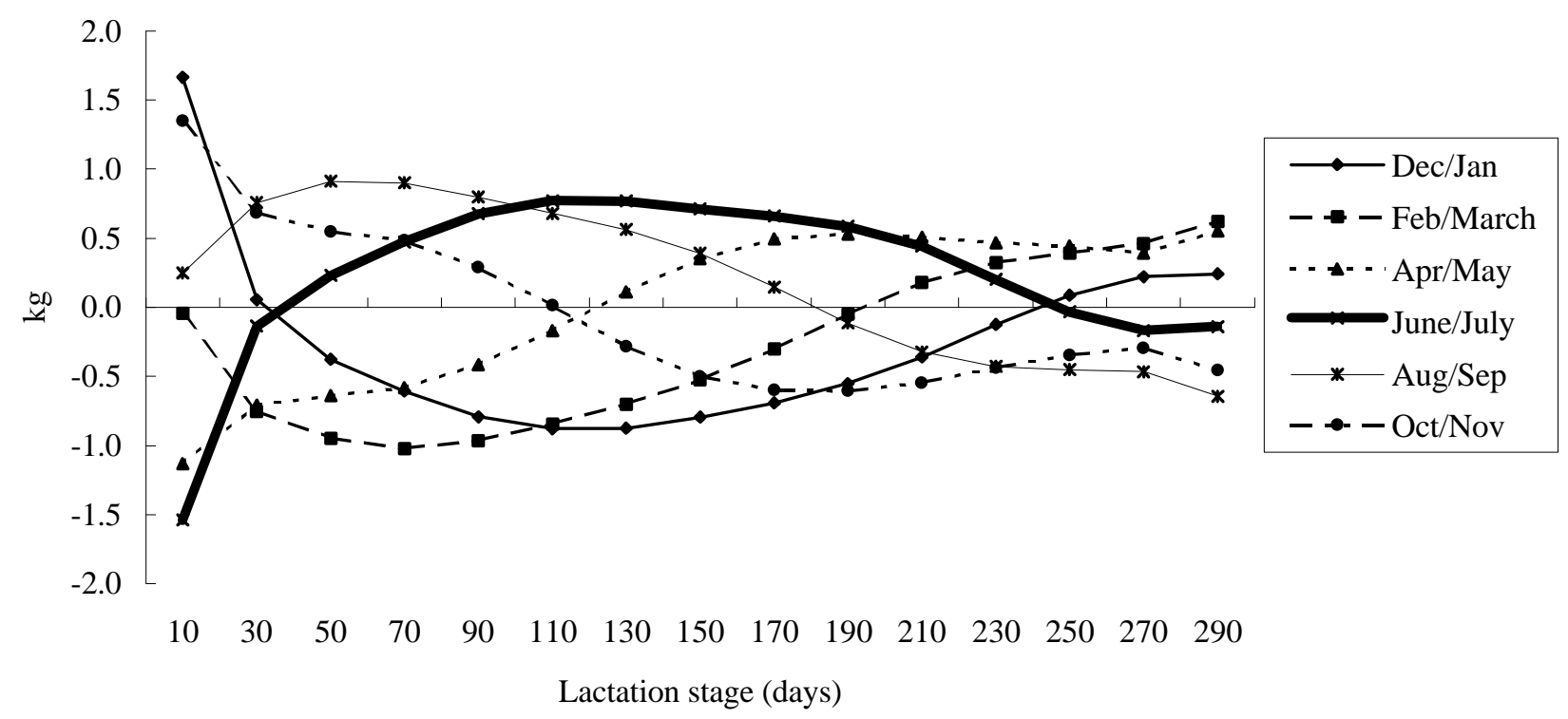

Figure 3 Effect of season of calving on daily milk yields of Jersey cows.

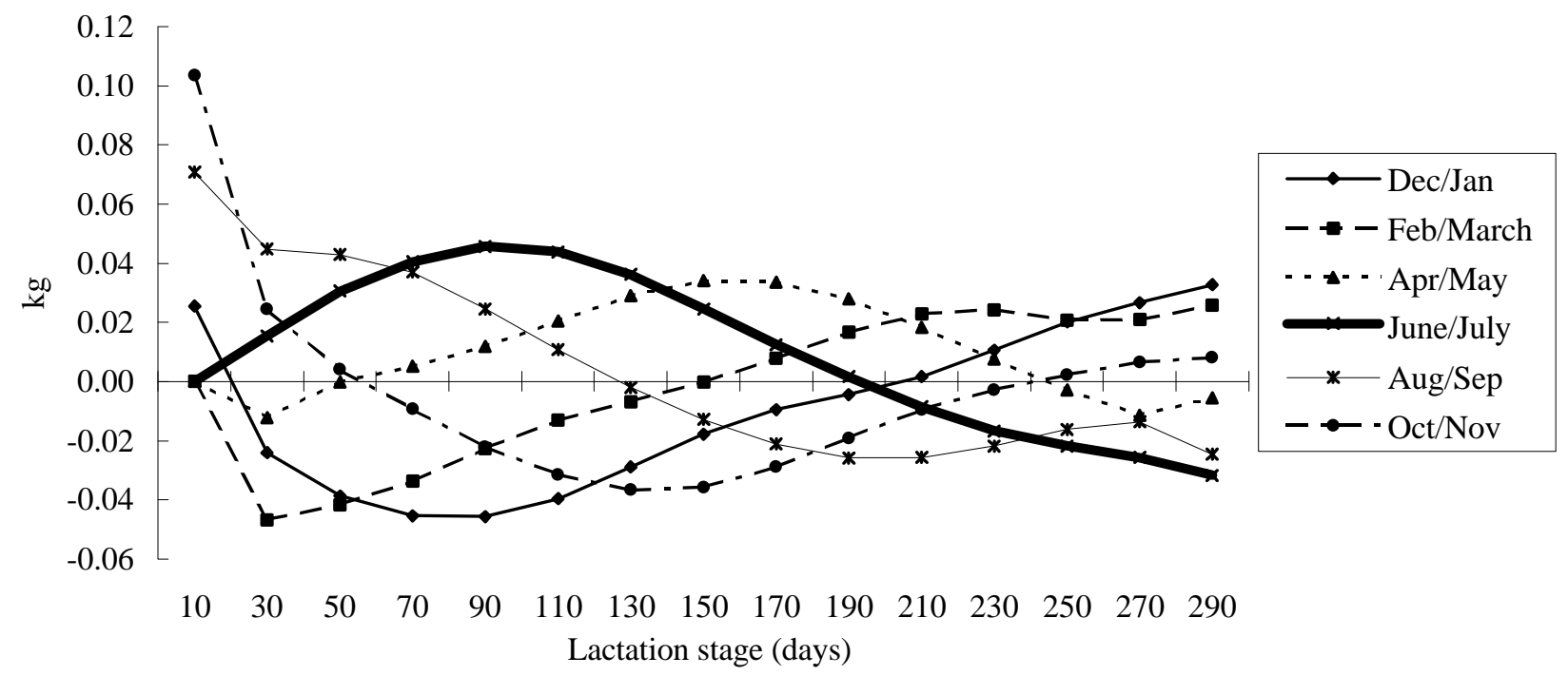

Figure 4 Effect of season of calving on daily protein yield of Holstein cows. 
Wilmink (1987b) reported that spring calving Friesian cows in the Netherlands had the highest daily milk yield in early lactation, whereas autumn calving cows had the highest production later in lactation. A similar pattern was observed for daily protein yield. For daily butterfat yield he reported that cows calving in April-July produced less than average over almost the entire lactation, whereas cows calving in October-January produced more. Similar results were reported by Olori \& Galesloot (1999) for Holstein cows in Ireland and for Holstein cows in Hungary (P.J.B. Galesloot, 2000. Personal communication).

Best Linear Unbiased Estimates of the effect of season of calving on 305-day milk yield and 305-day butterfat and protein yields are presented in Figures 5 and 6, respectively. Holstein cows calving in winter produced $186 \mathrm{~kg}$ more milk than Holstein cows calving in summer. For the Jersey breed this difference amounted to $150 \mathrm{~kg}$. Differences of $6 \mathrm{~kg}$ in 305-day protein yield between Holstein cows and $5 \mathrm{~kg}$ between Jersey cows calving in winter vs. summer, were observed. For 305-day butterfat yield in the Holstein breed, cows calving in Apr/May had the highest yields and in the Jersey breed cows calving in June/July had the highest yields. The lowest 305-day butterfat yields for both breeds were observed when cows calved in December/January. For the Holstein breed a difference of $8 \mathrm{~kg}$ in 305-day butterfat yield was observed between cows calving in April/May vs. December/January, and for the Jersey breed a difference of $4.5 \mathrm{~kg}$ was observed between cows calving in June/July vs. December/January.

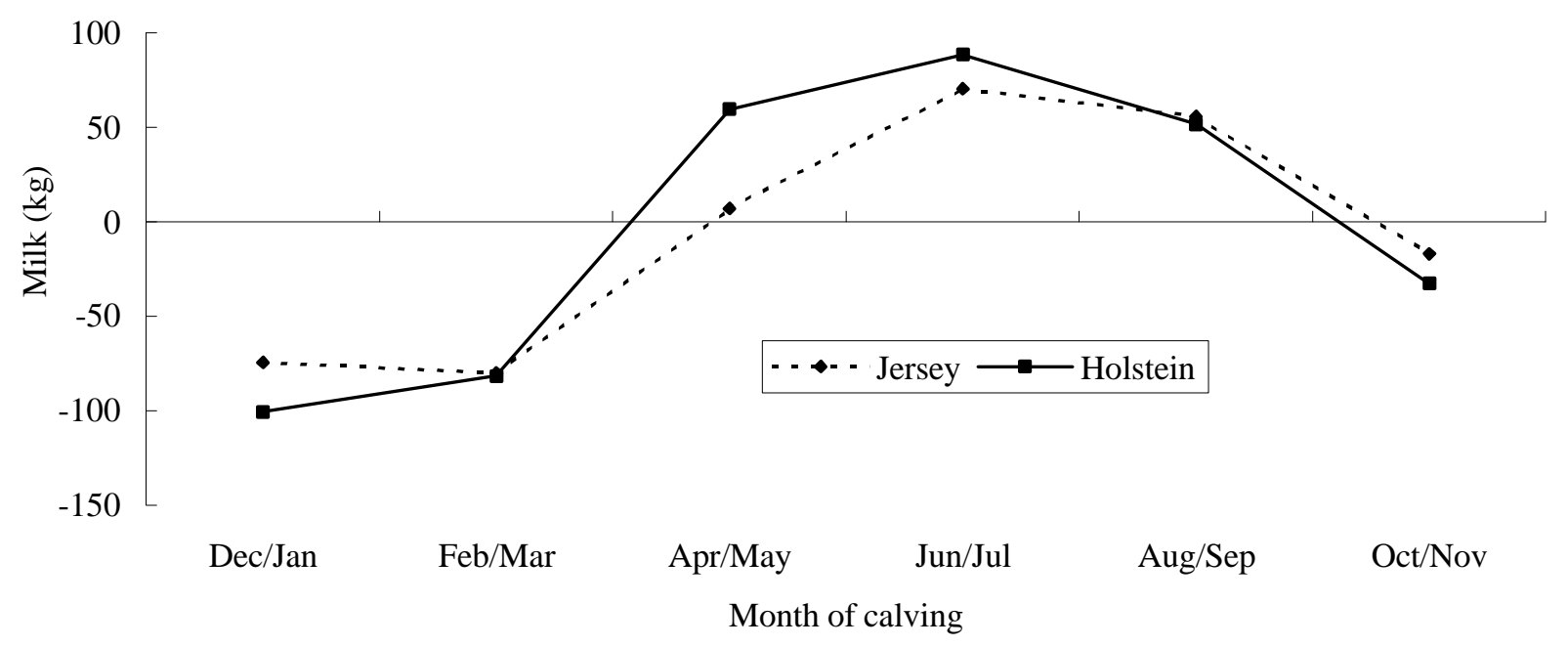

Figure 5 The effect of season of calving on 305-day milk yield of Holstein and Jersey cows.

Results of this study are similar to those reported in the literature. Olori \& Galesloot (1999) reported a difference of $368 \mathrm{~kg}$ in 305-day milk yield between Holstein cows calving in spring (April/May) vs. autumn (October/November) in Ireland. Corresponding differences in butterfat and protein yields were $15 \mathrm{~kg}$ and 10 $\mathrm{kg}$, respectively. Rahmat (1999) reported an effect of season of calving on milk yield and lactation length in Pakistan, with the highest milk yield being derived when Holstein-Friesian cows calved in autumn. Saxena $e t$ al. (1998) reported that cows calving in winter and spring had a higher milk yield than those calving in summer and autumn in India. Mahak et al. (1997), Narang et al. (1997), Mekonnen et al. (1998) and Hernandez \& Baca (1998) also found that calving season affected dairy performance. However, Bangar \& Narayankhedkar (1998) reported that lactation yield tended to be higher for cows calving in summer compared to winter and the rainy season in India, while Mishra et al. (1999) reported seasonal differences in milk yield per day of calving interval, but observed that milk production efficiency was highest in the summer calving season for half-bred Jersey and half-bred Holstein cows on the plains of Eastern India. 


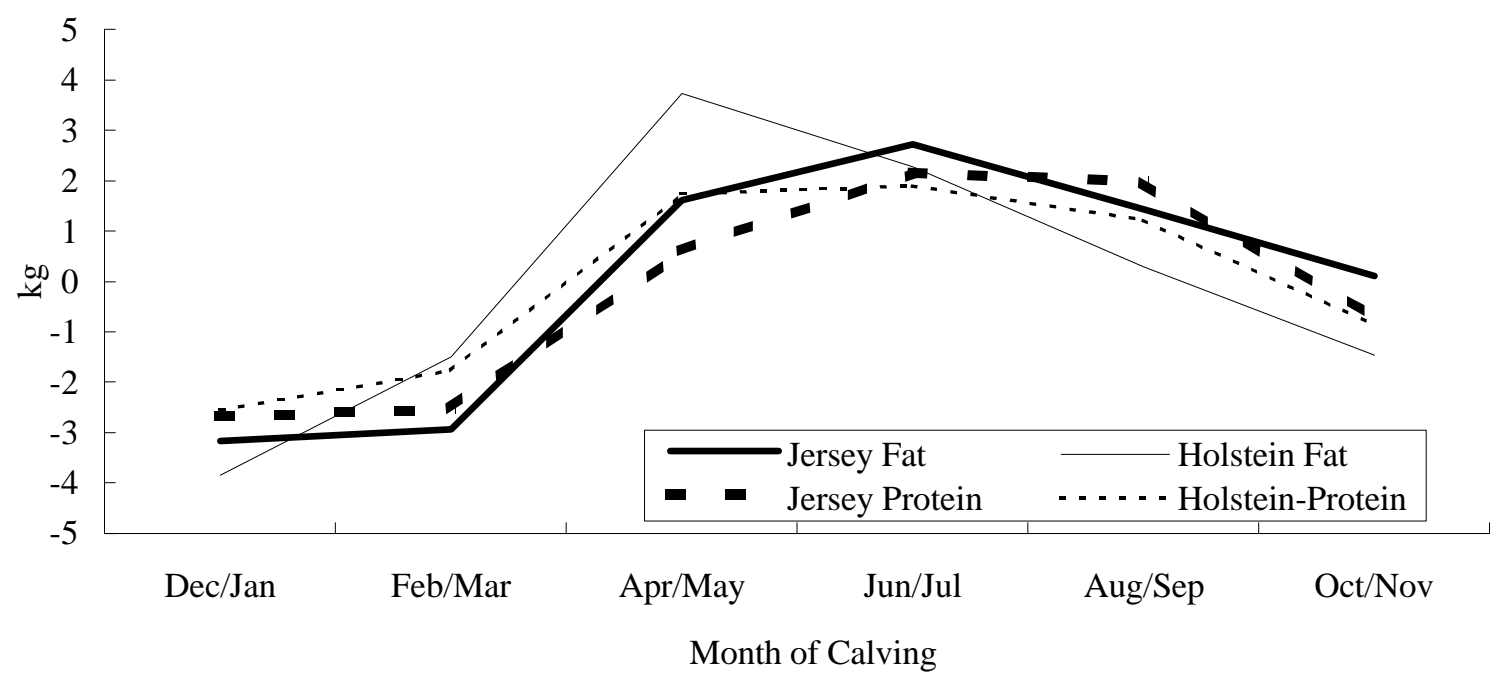

Figure 6 The effect of season of calving on 305-day butterfat and protein yields of Jersey and Holstein cows.

The Best Linear Unbiased Estimates of the effect of calving age $\mathrm{x}$ lactation for individual daily milk yields of Holstein cows and butterfat yields of Jersey cows are presented in Figures 7 and 8 respectively. Except for estimates of the Holstein runs being greater than those of the Jersey runs, calving age had the same curvilinear effect on all traits of both breeds. Kassab \& Salem (1999) also found that all milk yield traits showed a curvilinear relationship with age at calving. In this study daily yields early in the lactation were influenced to a greater extent by calving age than daily yields towards the end of the lactation. Cows that calved at younger ages in lactations 1 and 2 produced less milk over the entire lactation compared to cows calving at older ages. Second and later parity cows had higher test-day yields than heifers for most stages of lactation. The differences were greatest at the beginning of lactation and were almost zero or even negative after 230 days post partum. Olori \& Galesloot (1999) reported similar results for Holstein cows in Ireland, as did Wilmink (1987b) for Friesian cows in the Netherlands.

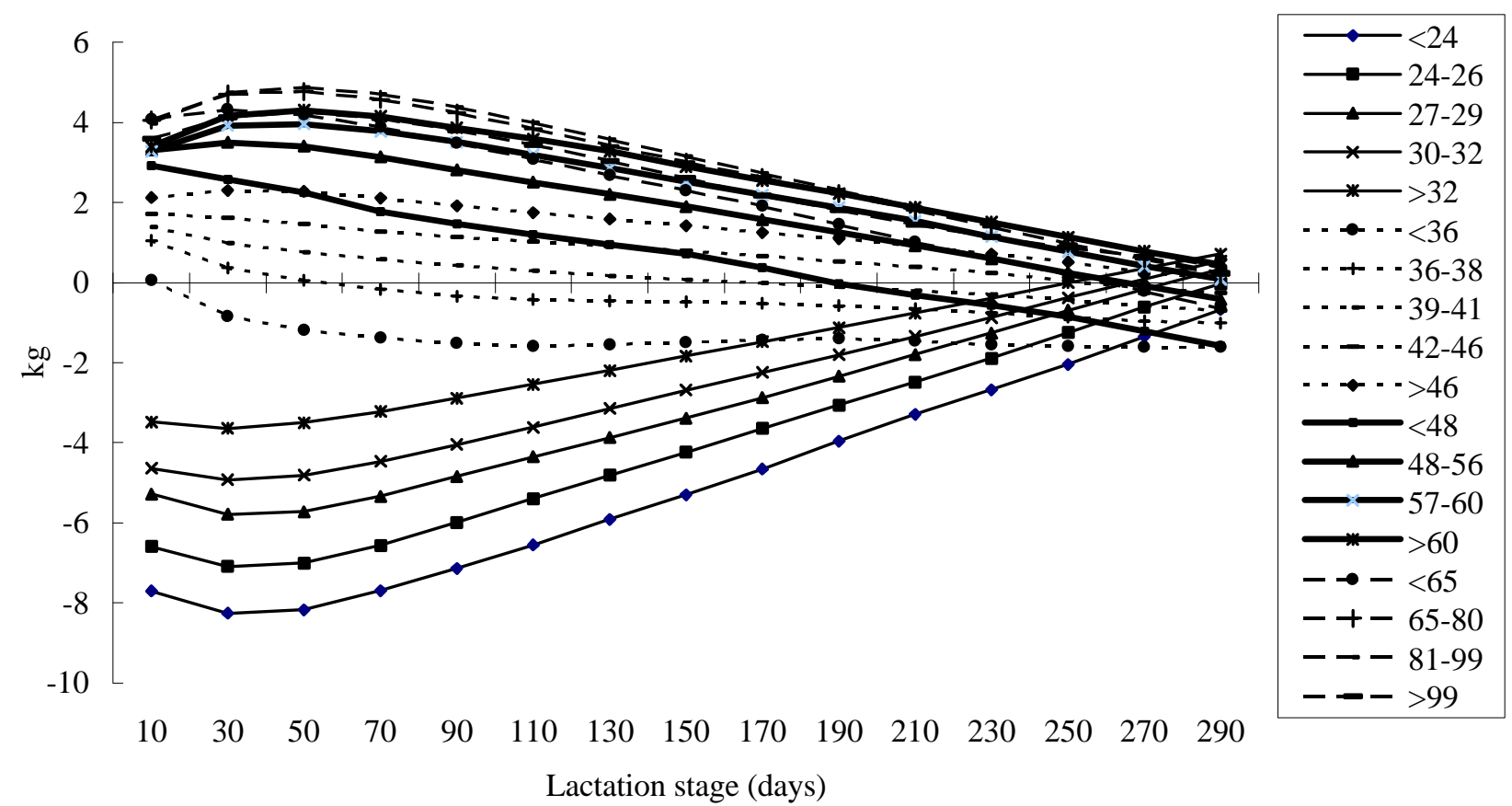

Figure 7 Effect of age $\mathrm{x}$ lactation on daily milk yield at different stages of lactation for Holstein cows. 


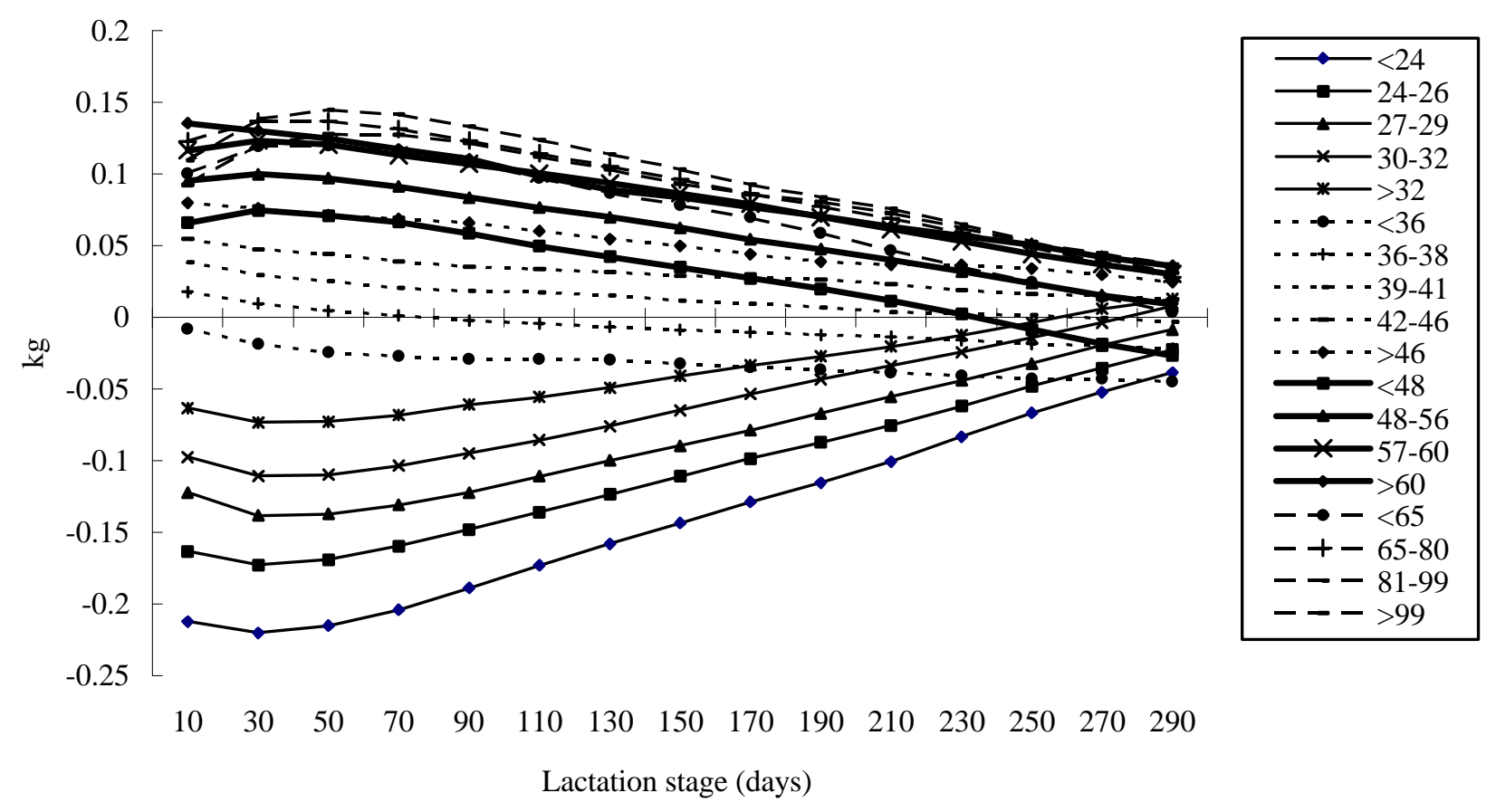

Figure 8 Effect of calving age x lactation on daily butterfat yield at different stages of lactation for Jersey cows.

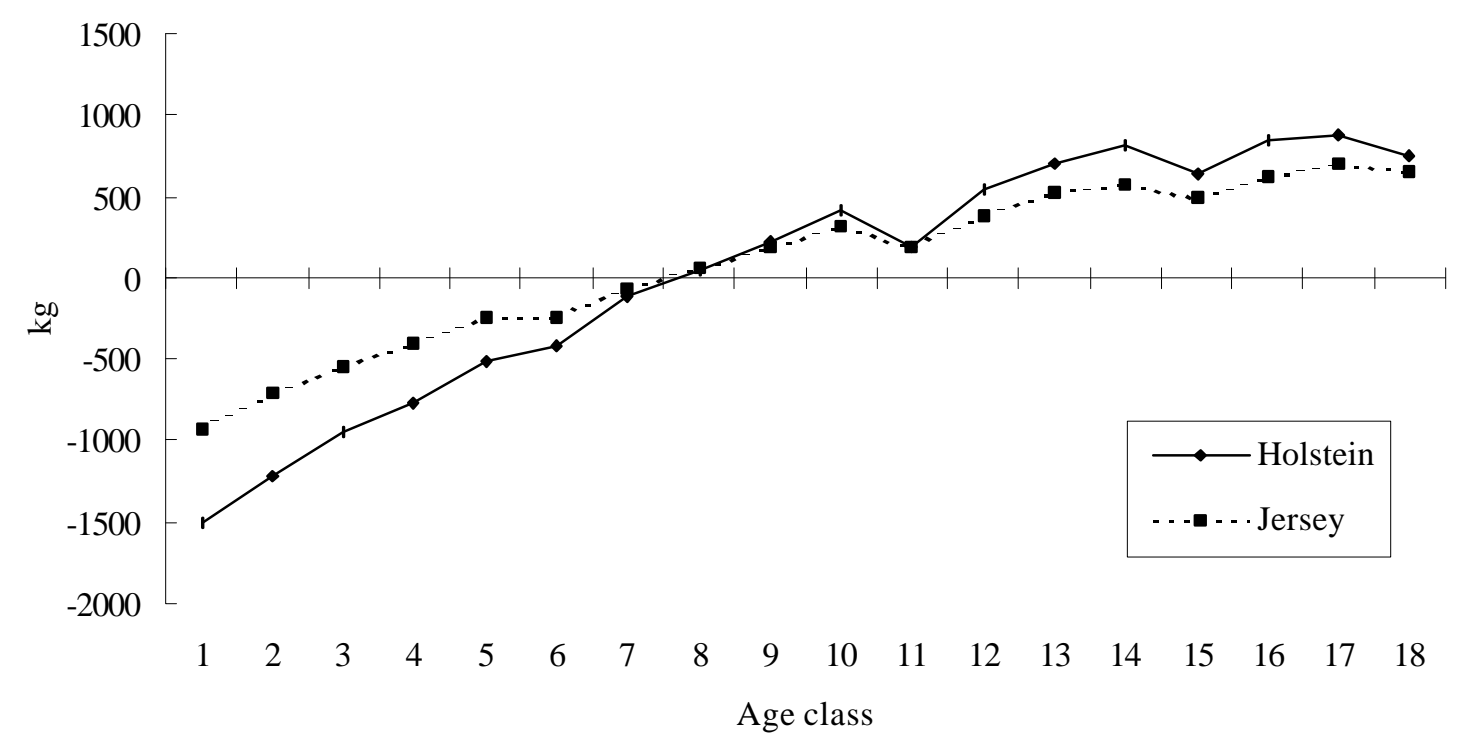

Figure 9 The effect of age x lactation on 305-day milk yield of Jersey and Holstein cows.

Best Linear Unbiased Estimates of the effect of calving age $\mathrm{x}$ lactation on 305-day milk, butterfat and protein yield are shown for Jersey and Holstein cows in Figures 9 and 10. The same trends were observed for all traits and for both breeds. Linear increases in yields with an increase in calving age were observed up to age class 14, i.e. cows older than 60 months of age at calving in lactation 3. After age class 17 (cows older than 99 months of age in lactations 4 or later) the curve flattened and declined. The dips in the curves at age classes 6,11 and 15 are at the start of lactations 2, 3 and 4 or later, respectively. The cows from these age classes are on average younger than those of the previous age classes, indicating that younger cows have lower yields. The average 305-day yield of cows calving at ages younger than 24 months was $1511 \mathrm{~kg}, 52 \mathrm{~kg}$ and $45 \mathrm{~kg}$ below the mean milk, butterfat and protein yield for Holstein cows and $927 \mathrm{~kg}, 42 \mathrm{~kg}$ and $33 \mathrm{~kg}$ below 
the mean for Jersey cows. Olori \& Galesloot (1999) reported corresponding averages of $903 \mathrm{~kg}, 30 \mathrm{~kg}$ and 32 $\mathrm{kg}$ for Holstein cows in Ireland calving at ages earlier than 24 months.

Mean 305-day yields were highest for cows of both breeds that calved from 81 to 99 months of age, i.e. $4^{\text {th }}$ or later lactation. In the case of the Holstein breed, these cows produced $885 \mathrm{~kg}$ more milk, $29 \mathrm{~kg}$ more butterfat and $24 \mathrm{~kg}$ more protein and in the case of the Jersey breed, these cows produced $703 \mathrm{~kg}$ more milk, $29 \mathrm{~kg}$ more butterfat and $22 \mathrm{~kg}$ more protein than the mean yield of all cows. Although it is clear from Figures 9 and 10 that the lowest 305-day yields were obtained from cows in their first lactation (age classes 1 to 5), most cows subjected to milk recording during this period were in their first lactation (35\% for both breeds) and less were in their $3^{\text {rd }}$ lactation (17\% for both breeds). A significant increase in herd economy could therefore be expected if breeders kept their cows for at least four lactations. Olori \& Galesloot (1999) reported that mean milk and protein yields were highest for Holstein cows in Ireland aged between 72 and 79 months at calving in lactations four or later. These cows produced about $480 \mathrm{~kg}$ more milk and $15 \mathrm{~kg}$ more protein than the mean yield across lactations. Saxena et al. (1998) also reported that cows in the $5^{\text {th }}$ and $6^{\text {th }}$ parities had consistently higher milk yield than those in other parities. Kassab \& Salem (1999) also found that age correction factors for Friesian cattle in Egypt had similar trends and did not exhibit large differences between consecutive age categories for older cows, but showed relatively large differences for younger cows.

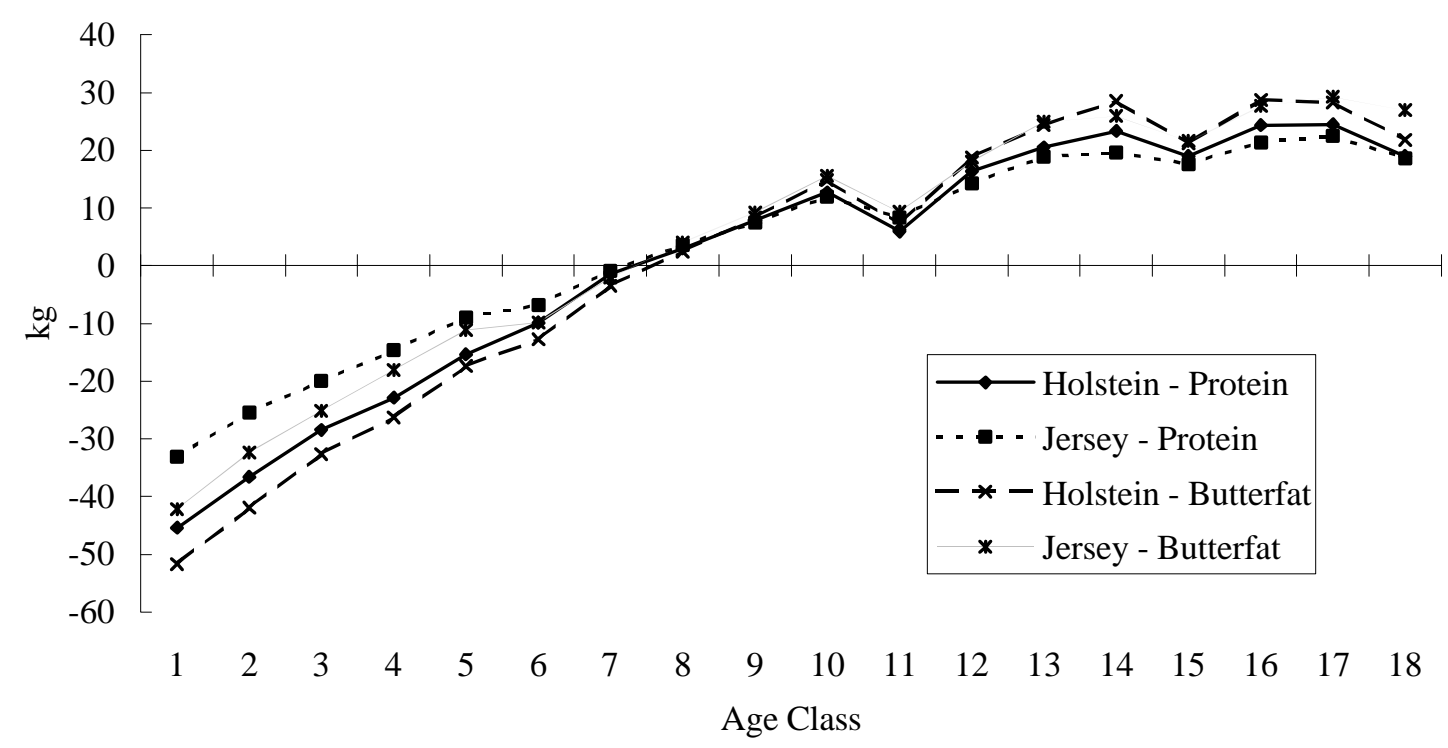

Figure 10 Effect of age x lactation on 305-day butterfat and protein yield of Jersey and Holstein cows.

\section{Conclusion}

Test-day records of heifers collected in early lactation and standardised for age and season are of potential value for early genetic evaluation of bulls and cows for 305-day yields. The estimates derived from this study can be used to adjust records for the effect of season and age class, enabling herd levels to be determined and standard lactation curves and projection factors to be derived. The results indicate that yields of South African dairy cattle are more variable than those reported for Holstein cattle in Ireland and the Netherlands.

\section{References}

Auran, T., 1973. Studies on monthly and cumulative monthly milk yield records. 1. The effect of age, month of calving, herd and length of the first period. Acta Agric. Scand. 24, 339-348.

Bangar, N.P. \& Narayankhedkar, S.G., 1998. Study on lactation curve in Gir and its crosses with Holstein Friesian and Jersey. Cheiron 27, 99-101.

Cooper, J.B. \& Hargrove, G.L., 1982. Age and month of calving adjustments of Holstein protein, milk and fat lactation yields. J. Dairy Sci. 65, 1673 - 1678.

Danell, 1982. Studies on lactation yield and individual test-day yields of Swedish dairy cows. 1. 
Environmental influence and development of adjustment factors. Acta Agric. Scand. 32, 65-81.

Dommerholt, J., 1975. Correctie van de melkgift van koeien voor verschillen in leeftijd, seizoen en lactatiestadium. Agricultural Research Reports 844. Centre For Agricultural Publishing and Documentation, Wageningen.

Du Toit, F. \& Hallowell, G.H. (Eds.), 2001. National Animal Improvement Scheme, Newsletter No 7, May 2001.

Groeneveld, E. \& Kovac, M., 1990. A generalised computing procedure for setting up and solving mixed linear models. J. Dairy Sci. 73, 513-531.

Hernandez, J. \& Baca, D., 1998. Effect of tuberculosis on milk production in dairy cows. J. Amer. Vet. Med. Ass. 213, 851-854.

Kassab, M.S. \& Salem, A.Y., 1999. Age correction factors for milk yield traits in a commercial herd of Friesian cattle in Egypt. Alexandria J. Agric. Res. 44, 1-14.

Mahak, S., Tomar, S.P.S., Rajvir, S., Manglik, V.P., Singh, M. \& Singh, R., 1997. Studies on exotic germplasm infused on Sahiwal to enhance milk production under the foothills of Uttar Pradesh. Indian J. Anim. Res. 31, 47-50.

Mekonnen, Y., Sada, I. \& Stipkova, M., 1998. Dairy and reproductive performance of imported Holstein cattle. Czech. J. Anim. Sci. 43, 305-311.

Mishra, R.K., Roy, P.K. \& Pal, P.K., 1999. Milk production efficiency of halfbred Jersey and halfbred Holstein cows in the plains of Eastern India. Indian J. Anim. Health 38, 111-113.

Narang, R., Manuja, N.K., Deept, I., Thakur, Y.P. \& Katoch, S., 1997. Factors affecting test-day milk yields and their use in prediction of lactation milk yield in Holstein-Friesian x Sahiwal crossbred cows. Himachal J. Agric. Res. 23, 105-111.

Olori, V.E. \& Galesloot, P.J.B., 1999. Projection of records in progress and calculation of 305-day yields for dairy cattle in the Republic of Ireland. A Report of the Animal Evaluation Project Number 01. Prepared for the Irish Cattle Breeding Federation (ICBF).

Rahmat, J.A., 1999. Productive performance of Holstein-Friesian cattle in North West Frontier Province (NWFP) of Pakistan. Pakistan Vet. J. 19, 192-196.

SAS, 1996. SAS user's guide : Statistics, Release 6.12. SAS Institute Inc., Cary, North Carolina, USA.

Saxena, M.M., Pandey, H.S., Suman, C.L., Pandey, H.N. \& Srivastava, B.B., 1998. Pre and post partum body weight changes in relation to milk yield in three breed crosses. Indian J. Anim. Prod. Managem. 14, 94-101.

Schaeffer, L.R. \& Burnside, E.B., 1976. Estimating the shape of the lactation curve. Can. J. Anim. Sci. 56, 157-170.

Wilmink, J.B.M., 1987a. Studies on test-day and lactation milk, fat and protein yield of dairy cows. Phd Proefschrift, Wageningen, Netherlands.

Wilmink, J.B.M., 1987b. Adjustment of test-day milk, fat and protein yield for age season and stage of lactation. Livest. Prod. Sci. 16, 335-348. 